DOI: 10.35218/armca.2019.1.02

\title{
A Group of Reliefs from the Mramba Village (the Republic of Abkhazia): To the Question of Dating
}

\author{
Ekaterina Yu. Endoltseva*
}

\begin{abstract}
Article deals with a group of reliefs from the church in Mramba village. Their were dated by the paleochristian period. New findings of the last ten years permit to adjust this version. They can be now referred to the Medieval period (10 - 11 century).
\end{abstract}

Keywords: reliefs, animals, architectural decoration, Abkhazia, zoomorphic

A long-term research cooperation with archaeologists from Abkhazia, in particular with G. A. Sangulia ${ }^{1}$, provided the author with the archaeological material of the repository of the State Department for the Protection of Historical and Cultural Heritage of the Republic of Abkhazia. The artefacts excavated in various parts of Abkhazia by archaeologists, members of the Department, have been deposited there since long ago. Following the reconstruction of the Abkhaz State Museum that took place between 2010 and 2012 some of its exhibits have been transferred to this repository as well.

The present study focuses on the analysis of the relief originating from the village of Mramba, in the vicinity of Tsebelda Valley. The image is cut on a limestone slab $(75 \times 47 \times 17 \mathrm{~cm})$ of a trapezoidal shape (Fig. 1). An equal-ended cross, which may be inscribed in a circle (Fig. 2), with crossbars extending towards the ends, is in the middle of the composition. There are ornamental convex circles of a small diameter at the corners of the crossbars. The arms of the cross are decorated along the centerline with multi-petal flower-type rosettes (two of them have survived, whereas the remaining two may be reconstructed). The cross is framed by a grapevine with bunches of grapes. It is of note that all the images are very conventional and schematic. As for the size, grapes are small, being of an oval shape and with a flat

\footnotetext{
${ }^{*}$ Researcher Institut of Oriental Studies, Russian Academy of Sciences, Moscow, kendoltseva@ivran.ru, https://orcid.org/0000-0003-1558-2819

${ }^{1}$ The author acknowledges the help of G. A. Sangulia, head of the State Department for the Protection of Historical and Cultural Heritage of the Republic of Abkhazia prior to the inclusion of this institution in the Ministry of Culture and the Protection of Historical and Cultural Heritage of Abkhazia in 2014.
} 
surface. There is a bird flying up to the cross, pecking a bunch of grapes, in the upper right corner of the plate. The bird is shown quite schematically as well: its oblong beak and the plumage of the wings are suggested by long parallel lines; there are short oblique notches on its back. The eye is marked by a semicircular stroke.



Fig. 1

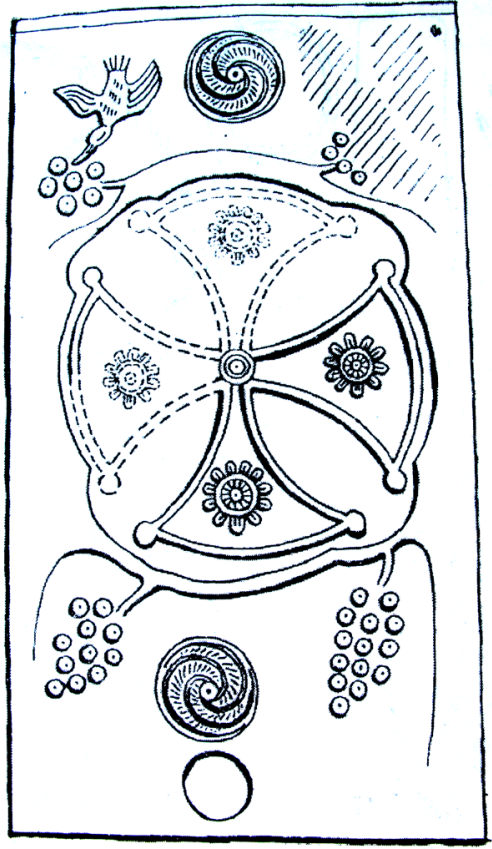

Fig. 2 
One of two vortical rosettes, which, judging by the drawings, published by L. G. Khrushkova ${ }^{2}$ and Yu. N. Voronov ${ }^{3}$, were on both sides of the cross, is preserved in the same part of the composition as well as the bird. In its current state, the plate is split into several fragments, its left and right upper corners being lost. The surface of the slab is significantly damaged: the top and the right crossbars with rosettes inside have practically faded, the vortical rosette on the left side of the cross being lost. On the other hand, the second vortical rosette (on the right side of the cross) is preserved quite well.

\section{The History and the Origin of the Monument}

The artefact in question has been discovered by archaeological researches from 1960 to 1971, under the direction of Yu. N. Voronov, V. S. Orelkin, and A. A. Saltykov, along with several other carved slabs:

- plate with an image of the cross of a similar shape in a circle (Fig. $3)^{4}$;

- plate with a four-petal rosette in a rectangular frame (Fig. 4)

- plate with two birds pecking grapes (Fig. 5) ${ }^{6}$.

The finds have been made on the site of the once destroyed and later restored church in the village of $\mathrm{Mramba}^{7}$. First mention of this church is in the scholarly literature of 1923, when "a local peasant found many gravestones under "miraculous' circumstances" ${ }^{8}$. V. I. Strazhev states that the temple in Mramba was restored ${ }^{9}$ in the 1920 s by the Greek immigrants ${ }^{10}$. In the course of this restoration the above-mentioned reliefs were used as spoliae, therefore it is unfortunately impossible to establish their connection with layer of any particular epoch.

\footnotetext{
${ }^{2}$ L.G. Khrushkova, Skul'ptura rannesrednevekovoi Abkhazii $V-X$ veka [Sculpture of the Early Medieval Abkhazia of the 5th-10th Century], Tbilisi, 1980, Tab. XIX, 1.

${ }^{3}$ Yu.N. Voronov, Nauchnye trudy: $v 7$ t. T. III. Taina Tsebel'dinskoi doliny. Drevnyaya Apsiliya [Scientific Works: in 7 volumes. Volume III. The Mystery of the Tsebelda Valley. Ancient Apsilia], Sukhum, 2010, p. 103, fig. 40.

${ }^{4}$ L.G. Khrushkova, Skul'ptura... tab. XIX, 3.

${ }^{5}$ Ibid., tab. XXII, 1.

${ }^{6}$ L.G. Khrushkova, Relief Slab with the Image of Birds from Tsebelda, Sovetskaya arkheologiya [Soviet Archeology], 1977, no. 1, p. 76, fig. 1.

${ }^{7}$ Yu.N. Voronov, Nauchnye Trudy..., p. 431.

${ }^{8}$ V.I.Strazhev, Abkhazia of Ruins, Izvestiya Abkhazskogo nauchnogo obshchestva [News of the Abkhazian Scientifi c Society], issue 1, Sukhum, 1925, p. 161.

${ }^{9}$ Ibid.

${ }^{10}$ Yu.N. Voronov, Nauchnye Trudy..., p. 431.
} 


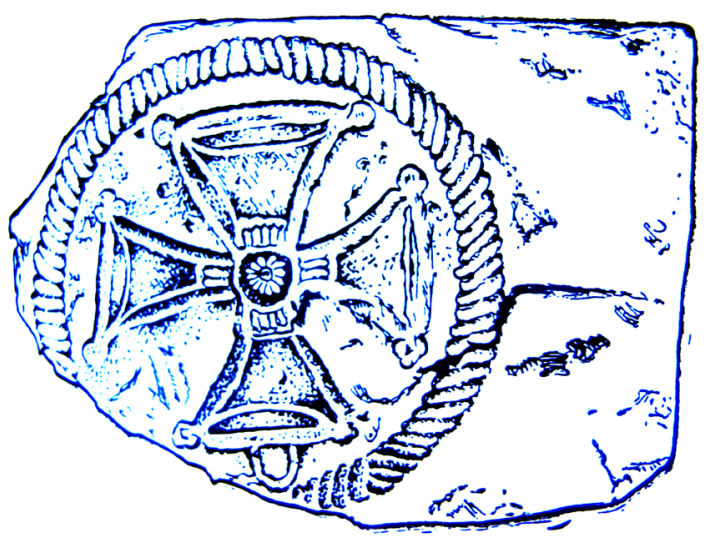

Fig. 3

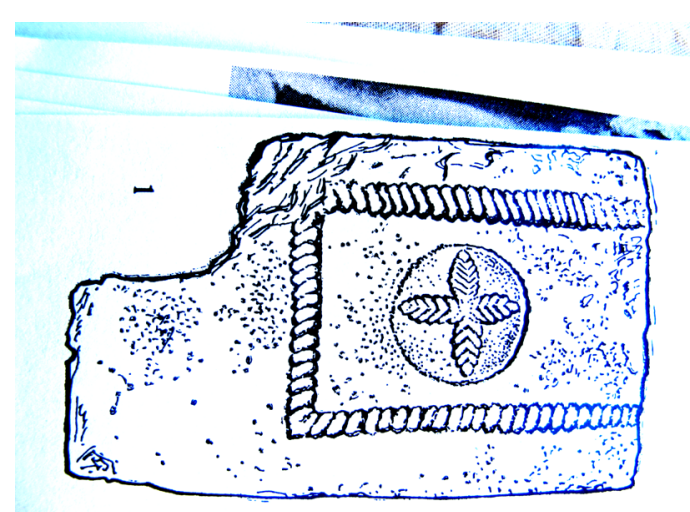

Fig. 4

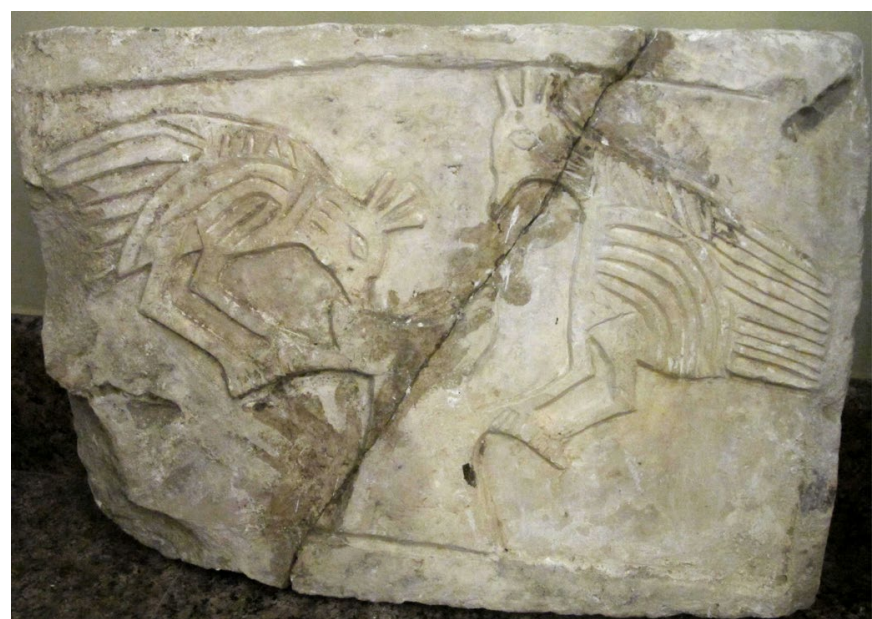

Fig. 5 
In the period 1981-1982 the Tsebelda archaeological expedition found at this place the remnants of an early Christian single-nave church with a protruding apse (pentahedral outside and horseshoe inside). The relief with the image of the fish (Fig. 6) ${ }^{11}$, window topping, and antefix with the image of the cross were found as well. It is with this building that $\mathrm{Yu}$. N. Voronov identifies the monuments found in the period 1960-1971, as follows: two reliefs with the images of the crosses; a plate with a cross and a grape with a bird; a plate with the image of the birds, as well as a newly found relief with fishes. Thanks to the archaeological research of 1981-1982 it also turned out that between the 11 th and the 14th centuries this early Christian church was restored from the ruins ${ }^{12}$.

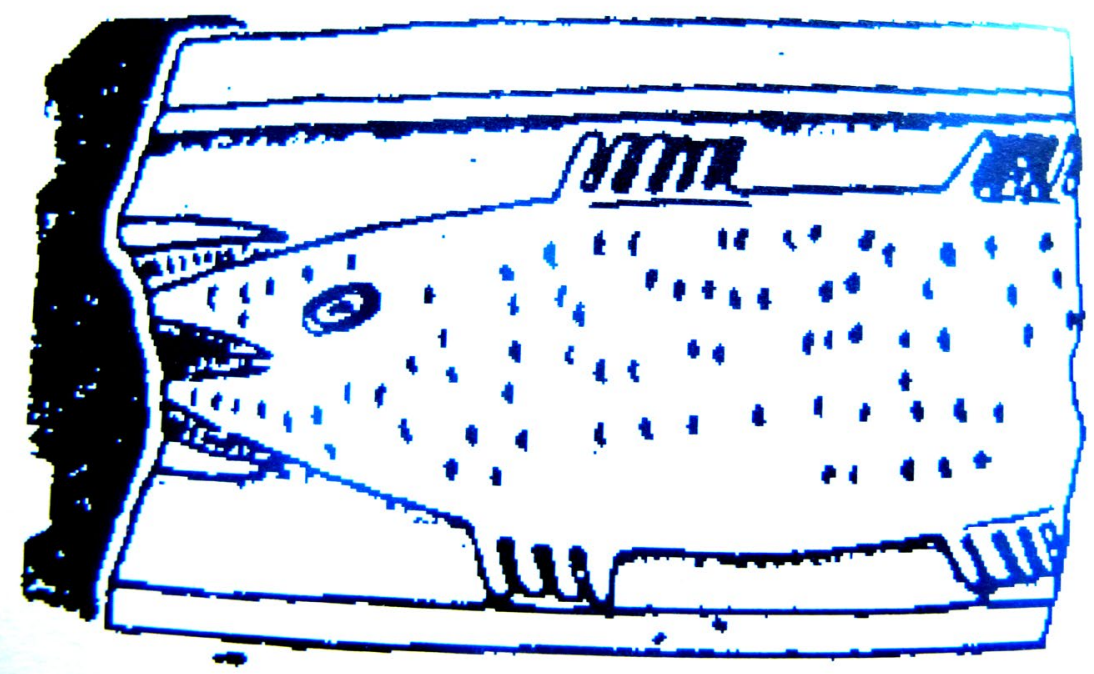

Fig. 6

\section{Stylistic and Iconographic Parallels}

L. G. Khrushkova assumes that the carved slabs and other fragments originating from the church in Mramba were collected at this place later and can be referred to two or three different temples ${ }^{13}$. However, the images on these artefacts betray a significant stylistic similarity. For example, a cross on the first plate (with a vine, a vortical rosette and a bird) is shaped like a cross in a circle from the second plate. In both cases, there are identical ornamental

11 Yu.N. Voronov, O.Kh. Bgazhba, Studies of Medieval Monuments in Tsebelda, Arkheologicheskie otkrytiya 1981-1982 gg. v Abkhazii [Archaeological Discoveries of 1981-1982 in Abkhazia], Tbilisi, 1985, p. 33, Table XXVI, 3.

12 Yu.N. Voronov, Nauchnye Trudy..., p. 431.

${ }^{13}$ L.G. Khrushkova, Skul'ptura ..., p. 32. 
motifs: flower-shaped rosettes (in the middle of the crossbar in the former case and in the crossing in the latter); convex circles of small diameter (in both cases at the corners of equal-ended crosses extending from the center of the crossbars). In addition, a circle-shaped braid framing a cross on the second slab is made in the same technique as the four-petal rosette and its rectangular ornamental frame on the third slab. In both cases, the twisted braid pattern is made with short diagonal notches in the characteristically flat relief.

The plumage of two birds drinking from a bowl depicted on a plate from the Abkhaz State Museum (probably peacocks, according to the tufts of three feathers on their heads), judging by the technique, resembles that of a bird on the first plate (with a cross and vortical rosettes) pecking grapes. In both cases, there are diagonal parallel notches on the wings. Besides, identical on both plates is the treatment of the elongated beak and the eyes (they are created by symmetrical semicircular strokes). The artistic image, created by simple technical means (parallel and symmetrical notches of different lengths), which testify to a simple graphic style is worthy of note for the two plates.

Moreover, as L. G. Khrushkova ${ }^{14}$ has been noted, the abovementioned reliefs from Mramba are similar in style and technique to some of the reliefs with zoomorphic images from Mount Anakopia. For example, a plate depicting a fish with two cypresses from Anakopia (Fig. 7) ${ }^{15}$ is almost identical to the image of the fish on a plate from Mramba ${ }^{16}$. Unfortunately, the present location of this slab is unknown, it can be analyzed from a drawing published by Yu. N. Voronov and O. Kh. Bgazhba in $1985^{17}$ only. In both cases, the fishes have two short fins on each side of the body and their scales are indicated by the dots formed by small depressions on the surface of the image.

\footnotetext{
${ }^{14}$ Ibid., p. 32.

${ }^{15}$ E.Yu. Endoltseva (ed.), Iskusstvo Abkhazskogo tsarstva VIII-XI vekov. Khristianskie pamyatniki Anakopiiskoi kreposti [The Art of the Abkhazian Kingdom of the 8th-11th Centuries: Christian Monuments of the Anacopian Fortress], St. Petersburg, 2011, p. 119, fig. 3.

${ }^{16}$ Idem, The Image of Fish in the Facade Decoration of the Abkhazian Kingdom: Symbolism of the Image, Problemy arkheologii Kavkaza: (k 70-letiyu Yu.N. Voronova): sbornik materialov Mezhdunarodnoi nauchnoi konferentsii, posvyashchennoi 70-letiyu Yu.N. Voronova (10-11 maya 2011 g., g. Sukhum) [Proceedings of the International Scientifi c Conference Dedicated to the 70th Anniversary of Yu.N. Voronov "The Problems of Archeology of the Caucasus" (May 10-11, 2011, Sukhum)], Sukhum, 2011, p. 176, fig. 5.

${ }^{17}$ Yu.N. Voronov, O.Kh. Bgazhba, Studies of Medieval Monuments..., p. 33, tab. XXVI, 3.
} 


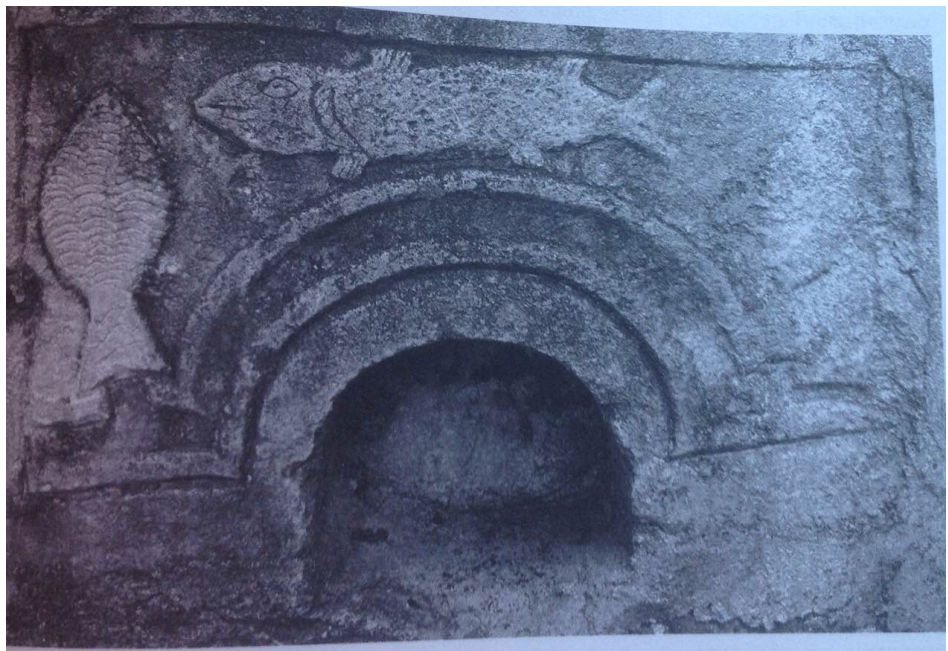

Fig. 7

Furthermore, a cross on a slab from the storage of the Department for the Protection of Historical and Cultural Heritage of the Republic of Abkhazia resembles a cross on a lost slab from Anakopia with a bull, a lion, and an inscription (Fig. 8) ${ }^{18}$, the only difference being that on the Anakopia plate the cross is ornamented even more simply and schematically. Instead of flower-shaped rosettes inside of each crossbar, there are but small drilled out dot-holes, no decorative circles being at the corners of the crossbars. The vortical rosettes on the plate with a lion from Anakopia (Fig. 9) are identical to those shown on the plate from the repository of the Department for the Protection of Historical and Cultural Heritage ${ }^{19}$ : a center in the shape of a decorative circle, three blades decorated with short diagonal notches.

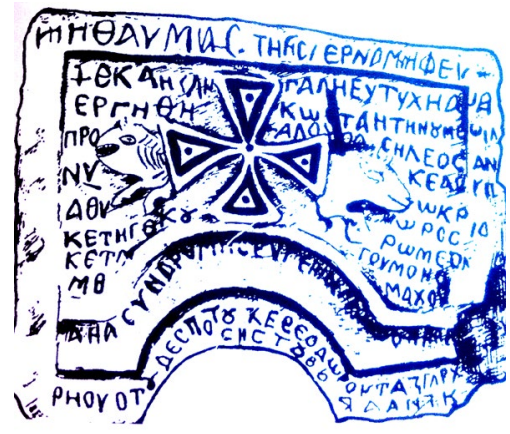

Fig. 8

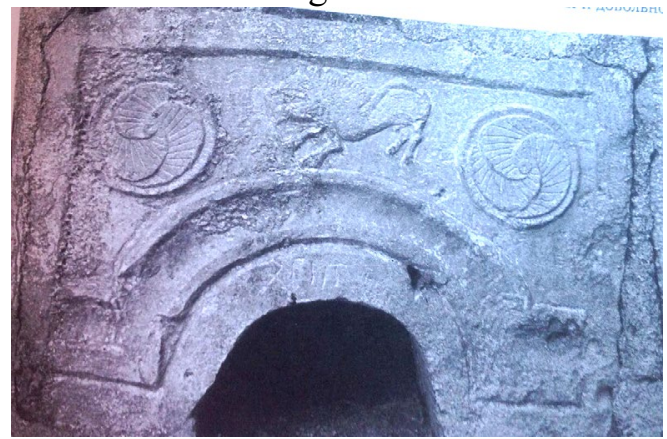

Fig. 9

To these two groups of monuments a relief from the Sukhumi mountain with the image of the cross with a bull and a lion (Fig. 10),

\footnotetext{
${ }^{18}$ E.Yu. Endoltseva (ed.), Iskusstvo Abkhazskogo tsarstva ..., p. 115, fig. 1.

${ }^{19}$ Ibid., p. 117, fig. 2.
} 
presently in the Abkhaz State Museum ${ }^{20}$, may be adjoined. This relief also shows an equal-ended cross with crossbeams extending from the crossing. There are, as on the first (with a cross, a bird, and a vine) and on the second (with a cross in a round frame of a twisted braid type) plates from Mramba, even a kind of flower-like rosettes placed along the centerlines of the crossbars in the former case and in the crossing in the latter one. It is true, the rosettes on the plate from the Sukhumi mountain are of an even more simplified form, rather like a four-petal flower bud. This motif is placed on the plate from the Sukhumi mountain not on the cross, but on a smooth background between the cross and the head of a lion.



Fig. 10

Images similar in style and iconography to those discussed above are also on capitals found by A. A. Miller in the altar of a small, late by construction time church on the territory of the fortress Tsybil ${ }^{21},{ }^{22}$. An equalended cross in a circle and bucrania are visible on this small capital. Both

\footnotetext{
${ }^{20}$ L.G. Khrushkova, Skul'ptura ..., tab. XVIII, 2.

${ }^{21}$ There is no information on the present location of the monument; it is known only from the publication of A. A. Miller.

${ }^{22}$ A.A. Miller, Explorations on the Black Sea Coast of the Caucasus in 1907, Izvestiya Imperatorskoi Arkheologicheskoi komissii [News of the Imperial Archaeological Commission], issue 33, St. Petersburg, 1909, p. 81, fig. 6; L.G. Khrushkova, Skul'ptura ..., tab. XXIII, 1 .
} 
motifs are rather widespread in the medieval temple plastics of the Northern Black Sea and Transcaucasus ${ }^{23}$.

\section{Dating}

A version proposed in a number of works by L. G. Khrushkova concerns the time of execution of these stylistically close images. In one of her earlier articles, where the relief with the image of the peacocks at the bow ${ }^{24}$ is being analyzed, the researcher notes reasonably that this motif is widespread both in early Christian and in medieval art. However, L. G. Khrushkova does not consider the plates from Mramba as coming from the same church. She notes neither stylistic similarity of their images, nor common features in the technique of execution.

As for the possible time of execution of the relief with birds, the researcher proposes the period between the 7th to the 9th centuries, referring to the "semantics of images, the features of execution, and the given analogies" 25 . In a later generalizing work devoted to the sculpture of early medieval Abkhazia, the author tends to an even earlier dating: the 6th to the 7 th centuries, although it is stipulated that "the rudeness of the execution ... makes it difficult to determine the date" ${ }^{26}$. She notes in the same study that such images of the birds are typical examples of medieval art in its entirety, this motif being found in folklore right up to the present day. Indeed, considering the technique of execution of the birds on the reliefs from Mramba and from the repository of the Department for the Protection of Historical and Cultural Heritage, as well as the iconographic features of these images (simplified schematic drawing and composition), one can find a number of analogies in the stone plastic of the period of the High Middle Ages, in the territory of Byzantine empire, as well as the regions under its direct influence.

Concerning these analogies a mention should be made of two peacocks carved on limestone slabs from the Church of St. George in Febe (Boeotia, 872) ${ }^{27}$, that is to say peacocks on a plate from Boeotia are made in a similar way ${ }^{28}$. They are close to the image of two birds on the Mramba plate by a tuft of three feathers on their heads and the designation of the

\footnotetext{
${ }^{23}$ E.Yu. Endoltseva, Syncretic Images in the Architectural Decoration of the south Caucasus in the Medieval Period: Bull's Head, Aktual'nye problemy teorii $i$ istorii iskusstva: VII Mezhdunarodnaya konferentsiya Sankt-Peterburg, 11-15 oktyabrya 2016 g.: tezisy dokladov [Actual Problems of Theory and History of Art: The 7th International Conference (St. Petersburg, October 11-15, 2016): conference abstracts], St. Petersburg, 2016, pp. 63 - 64.

${ }^{24}$ L.G. Khrushkova, Relief Slab with the Image of Birds from Tsebelda, Sovetskaya arkheologiya [Soviet Archeology], 1977, no. 1, pp. 75-83.

${ }^{25}$ Ibid., p. 82.

${ }^{26}$ L.G. Khrushkova, Skul'ptura ..., p. 35.

${ }^{27}$ A. Grabar, Sculptures Byzantines de Constantinople (IV-X Siècle), Paris, 1963, pl. XLIII, 3,4 .

${ }^{28}$ Ibid., pl. XLIII, 3.
} 
feathers with schematic parallel notches. Besides, the birds are always shown in profile. There are similarities with the Mramba reliefs in the manner of depicting two birds on the reliefs of the external apse wall of the Skripou Church (873-874) in Boeotia ${ }^{29}$. A bird on the burial slab of the 11 th century from Prespa is similarly made ${ }^{30}$. Like two birds from Mramba, he has a hooked elongated beak and paws with claws. The wings, as in the previous cases, are marked by sharp parallel lines. Interestingly, the sarcophagus of St. Sophia Cathedral in Kiev, 11 th c. ${ }^{31}$ also has a bird made in the abovementioned schematic graphic manner. Birds are identical in reliefs of the 11 th century from the Athenian Agora ${ }^{32}$. On the capitals from the church of Panagia Episkopi (XI century) on Santorini ${ }^{33}$ two birds are compositionally close to the feathered Mramba reliefs.

L. G. Khrushkova suggests dating the plates with crosses from Mramba to the 6th century. The researcher points to their iconographic analogies of the early Christian time ${ }^{34}$, however, she is perplexed by the presence of vortical rosettes on the "early Christian images". According to her, they are found in Christian plastic no earlier than the 8th century ${ }^{35}$. In her latest work L. G. Khrushkova, overlooking the contradictions noted above, relates all of the Mramba reliefs to the 6th century, considering them the work of local masters ${ }^{36}$.

A carved capital is found not far from Mramba in a medieval church of the fortress Tsybil and known from the publication of A. A. Miller, also dated by L. G. Khrushkova to the 6 th c. ${ }^{37}$. The dating is based upon the fact that in course of the excavations of 1977 the researcher found an earlier building under the foundation of the temple, this argument failing to be sufficiently convincing though. Similarly, one may put in question a hypothesis of $\mathrm{Yu}$. N. Voronov, worked out during the 1981-1982 excavations, when an earlier building (presumably of the 6th century) was discovered on the site of the Mramba church, to which the researcher has referred the reliefs with the "early Christian symbolism". The researcher himself has noted that this early Christian church, apparently, was restored between the 11 th and the 14 th centuries ${ }^{38}$.

\footnotetext{
${ }^{29}$ Ibid., pl. XL, 1-3.

${ }^{30}$ A. Grabar, Sculptures Byzantines du Moyen Âge. II. (XI-XIV Siècle), Paris, A. et J. Picard Publ., 1976, p. 64, pl. XXXVI a.

${ }^{31}$ Ibid., pl. LVII b.

32 Ibid., p. 104, pl. LXXX a.

${ }^{33}$ M. Dennert, Mittelbyzantinische Kapitelle. Studien zu Typologie und Chronologie, Bonn, 1997, taf. 54, 305.

${ }^{34}$ L.G. Khrushkova, Skul'ptura ..., p. 33.

${ }^{35}$ Idem, Relief Slab..., p. 81.

${ }^{36}$ L. Khroushkova, Les Monuments Chrétiens de la Côte Orientale de la Mer Noire, Abkhazie IV-XIV Siècles. Turnhout, 2006, (Bibliotheque de l'Antiquite Tardive 9), p. 86.

${ }^{37}$ L.G. Khrushkova, Skul'ptura ..., p. 37.

${ }^{38}$ Yu.N. Voronov, Nauchnye Trudy..., p. 431.
} 
One has to consider the fact that none of the motives mentioned above (equal-ended crosses, birds, fishes, bukrania, and grapevine) cannot be treated as exclusively early Christian. Each of them existed in art for quite a long time, over various periods, from early Christian to medieval one ${ }^{39}$.

There is an undoubted stylistic proximity between the Mramba carved slabs and some of the Anakopian reliefs, for example the reliefs with fishes, two plates with crosses, platbands with a lion and a bull at the cross with an inscription and with a lion with two vortical rosettes, and a plate from Sukhumi Mountain with a bull and a lion at the foot of the cross. It makes sense to note a certain similarity in the circumstances of the discovery of the Mramba reliefs and those from the Anakopian Mountain: the absence of a clear archaeological context, since both lapidary collections were formed in the late 19th-early 20th century on the site of ancient churches that survived different periods of renovations.

Recent studies of the Anakopia reliefs (iconographic and stylistic analysis, historical and paleographic context) have showed that since the inscription on the relief with a bull and a lion at the cross was made simultaneously with the image, not at different times, as was supposed ${ }^{40}$, they may be considered to be a work of medieval masters of the 11th century ${ }^{41}$. Given the marked stylistic and iconographic similarity of the monuments, this date seems to be the most suitable for Mramba carved plates. This hypothesis does not contradict any of the previously mentioned facts. On the contrary, the images similar to those discussed above, as already shown, are quite common in the Middle Ages, especially in the 10th-11th centuries. The remnants of an older early Christian building under the foundation of the Mramba church does not imply it being decorated with these reliefs. They could have been made at the time of the archaeologically determined renovation of this church between the $11^{\text {th }}$ and 14 th centuries.

If the proposed dating is correct, the reliefs from Mramba, Anakopia, and those from the Sukhumi mountain make up a special group of architectural decorations within such an artistic phenomenon as the art of the Abkhazian kingdom ${ }^{42}$. This has been repeatedly mentioned in different contexts $^{43}$. "Monuments of this group, the images on which as a whole ... are

\footnotetext{
${ }^{39}$ E.Yu. Endoltseva (ed.), Iskusstvo Abkhazskogo tsarstva ..., p. 101-142.

${ }^{40}$ L.G. Khrushkova, Skul'ptura ..., pp. 26-32.

${ }^{41}$ E.Yu. Endoltseva (ed.), Iskusstvo Abkhazskogo tsarstva ..., p. 87-209.

${ }^{42}$ Idem, Particularities of Formation of the Abkhazian Kingdom's Artistic Culture and its Contacts with Byzantium (On the Example of Architectural Decoration), Trudy Instituta vostokovedeniya RAN. Vyp. 9: Natsional'naya kul'tura $v$ transnatsional'nom prostranstve [Proceedings of the Institute of Oriental Studies of the Russian Academy of Sciences. Issue 9: National Culture in Transnational Space], Moscow, 2018, pp. 37-54.

${ }^{43}$ Idem, Some Particularities of the Abkhazian Kingdom's Art of the 8th-11th Centuries on the Example of Architectural Decoration, Aktual'nye problemy teorii i istorii iskusstva: tezisy dokladov VIII Mezhdunarodnoi konf., Moskva, 2-6 oktyabrya 2018 g. [Actual Problems of Theory and History of Art: Abstracts of the 8th International Conference (Moscow, October
} 
schematic and primitive both in terms of technique and composition ... are stylistically close to the monuments of the 10th-11th centuries originating from other regions of the Byzantine Empire (Cappadocia, Asia Minor, Greece), and from the territories that were at that time under its direct cultural influence (Kievan Russia)" "44. Publications of $2017^{45}$ equally corroborate the conclusions of the author of the present article.

This research is financed by Russian Fund for Fundamental researches, project № 18 -012- 00319 .

\section{List and source of illustrations:}

Fig. 1 Slab from the collection of the former State Department for the Protection of Historical and Cultural Heritage of the Republic of Abkhazia. Photo of the author.

Fig. 2 Sketch of the slab from the collection of the former State Department for the Protection of Historical and Cultural Heritage of the Republic of Abkhazia. From ${ }^{\wedge}$ Voronov Yu.N. Nauchnye trudy: v 7 t. T. III. Taina Tsebel'dinskoi doliny. Drevnyaya Apsiliya [Scientific Works: in 7 volumes. Volume III. The Mystery of the Tsebelda Valley. Ancient Apsilia]. Sukhum, 2010, p. 103, fig. 40.

Fig. 3 Cross in the circle. Sketch of the slab. From: Khrushkova L.G. Skul'ptura rannesrednevekovoi Abkhazii V-X veka [Sculpture of the Early Medieval Abkhazia of the 5th-10th Century]. Tbilisi, 1980, Tab. XIX, 3.

Fig. 4 Plate with a four-petal rosette in a rectangular frame. From: Khrushkova L.G. Skul'ptura rannesrednevekovoi Abkhazii V-X veka [Sculpture of the Early Medieval Abkhazia of the 5th-10th Century]. Tbilisi, 1980, Tab. XXII, 1.

Fig. 5 Slab with the image of two birds. Photo of the author.

Fig. 6 Sketch of the slab with the image of fishes. From: Voronov Yu.N., Bgazhba O.Kh. Studies of Medieval Monuments in Tsebelda, Arkheologicheskie otkrytiya 1981-1982 gg. v Abkhazii [Archaeological Discoveries of 1981-1982 in Abkhazia]. Tbilisi, 1985, p. 33, Table XXVI, 3.

Fig. 7 Slab with the image of the fish and two cypresses. Photo of the author.

Fig. 8 Sketch of the slab with the bull and lion near the cross. Form: Endoltseva E.Yu. (ed.) Iskusstvo Abkhazskogo tsarstva VIII-XI vekov. Khristianskie pamyatniki Anakopiiskoi kreposti [The Art of the Abkhazian Kingdom of the 8th11th Centuries: Christian Monuments of the Anacopian Fortress]. St. Petersburg, 2011, p. 115, Il. 1.

2-6, 2018)], St. Petersburg, NP-Print Publ., 2018, pp. 160-163. Available at: https://actualart.spbu.ru/images/2018/AA_thesis2018.pdf (accessed 17.12.2018).

${ }^{44}$ Idem, The Lashkendar Church and the Alan-Abkhazian Cultural Contacts: Prospects of Studying, Observatoriya kul'tury [Observatory of Culture], 2018, vol. 15, no. 3, p. 304.

45 T. Dadiani, T. Khundadze, E. Kvachatadze, Medieval Georgian Sculpture. Tbilisi, 2017. Endoltseva E.Yu. About One Relief from the Storage of the Former State Department for Protection of the Cultural Heritage of the Republic of Abkhazia, Arkheologiya srednevekovogo khrama: materialy Mezhdunarodnoi nauch. konf., posvyashchennoi 170-letiyu K.K. Kostsyushko-Valyuzhinicha, Khersones, 25-29 sentyabrya $2017 \mathrm{~g}$. [Proceedings of the International Scientific Conference Dedicated to the 170th Anniversary of K.K. KostsyushkoValyuzhinich "Archaeology of Medieval Church" (Chersonesus, September 25-29, 2017)], Sevastopol, 2017, pp. 21-24. 
Fig. 9 Slab from Anacopia mountain with the image of lion and two vortical rosettes. Photo of the author.

Fig. 10 Slab from the Sukhum mountain. Photo of the author.

\section{Bibliography:}

Dadiani T., Khundadze T., Kvachatadze E., Medieval Georgian Sculpture, Tbilisi, Cezanne Printing House, 2017, 375 p.

Dennert, M., Mittelbyzantinische Kapitelle, Studien zu Typologie und Chronologie. Bonn, Habelt Publ., 1997, 232 p.

Endoltseva, E.Yu. (ed.), Iskusstvo Abkhazskogo tsarstva VIII-XI vekov. Khristianskie pamyatniki Anakopiiskoi kreposti [The Art of the Abkhazian Kingdom of the 8th-11th Centuries: Christian Monuments of the Anacopian Fortress], St. Petersburg, RKhGA Publ., 2011, 272 p.

Endoltseva, E.Yu., About One Relief from the Storage of the Former State Department for Protection of the Cultural Heritage of the Republic of Abkhazia, Arkheologiya srednevekovogo khrama: materialy Mezhdunarodnoi nauch. konf., posvyashchennoi 170-letiyu K.K. Kostsyushko-Valyuzhinicha, Khersones, 25-29 sentyabrya $2017 \mathrm{~g}$. [Proceedings of the International Scientifi c Conference Dedicated to the 170th Anniversary of K.K. Kostsyushko-Valyuzhinich "Archaeology of Medieval Church" (Chersonesus, September 25-29, 2017)], Sevastopol, FGBUK GIAMZ "Khersones Tavricheskii" Publ., 2017, pp. 21-24 (in Russ.).

Endoltseva, E.Yu., Particularities of Formation of the Abkhazian Kingdom's Artistic Culture and its Contacts with Byzantium (On the Example of Architectural Decoration), Trudy Instituta vostokovedeniya RAN. Vyp. 9: Natsional'naya kul'tura $v$ transnatsional'nom prostranstve [Proceedings of the Institute of Oriental Studies of the Russian Academy of Sciences. Issue 9: National Culture in Transnational Space], Moscow, IV RAN Publ., 2018, pp. 37-54 (in Russ.).

Endoltseva E.Yu., Some Particularities of the Abkhazian Kingdom's Art of the 8th11th Centuries on the Example of Architectural Decoration, Aktual'nye problemy teorii $i$ istorii iskusstva: tezisy dokladov VIII Mezhdunarodnoi konf., Moskva, 2-6 oktyabrya $2018 \mathrm{~g}$. [Actual Problems of Theory and History of Art: Abstracts of the 8th International Conference (Moscow, October 2-6, 2018)], St. Petersburg, NPPrint Publ., 2018, pp. 160-163. Available at: https://actualart.spbu.ru/images/2018/AA_thesis2018.pdf (accessed 17.12.2018) (in Russ.).

Endoltseva E.Yu., Syncretic Images in the Architectural Decoration of the south Caucasus in the Medieval Period: Bull's Head, Aktual'nye problemy teorii i istorii iskusstva: VII Mezhdunarodnaya konferentsiya Sankt-Peterburg, 11-15 oktyabrya 2016 g.: tezisy dokladov [Actual Problems of Theory and History of Art: The 7th International Conference (St. Petersburg, October 11-15, 2016): conference abstracts], St. Petersburg, Sankt-Peterburgskogo Universiteta Publ., 2016, pp. 6364 (in Russ.).

Endoltseva E.Yu., The Image of Fish in the Facade Decoration of the Abkhazian Kingdom: Symbolism of the Image, Problemy arkheologii Kavkaza: (k 70-letiyu Yu.N. Voronova): sbornik materialov Mezhdunarodnoi nauchnoi konferentsii, posvyashchennoi 70-letiyu Yu.N. Voronova (10-11 maya 2011 g., g. Sukhum) [Proceedings of the International Scientifi c Conference Dedicated to the 70th Anniversary of Yu.N. Voronov "The Problems of Archeology of the Caucasus" (May 
10—11, 2011, Sukhum)], Sukhum, AbIGI im. D.I. Gulia Publ., 2011, pp. 170-178 (in Russ.).

Endoltseva E.Yu., The Lashkendar Church and the Alan-Abkhazian Cultural Contacts: Prospects of Studying, Observatoriya kul'tury [Observatory of Culture], 2018, vol. 15, no. 3, pp. 298 -308 (in Russ.). DOI 10.25281/2072-3156-2018-15-3298-308.

Grabar, A., Sculptures Byzantines de Constantinople (IV-X Siècle), Paris, Maisonneuve Publ., 1963, 139 p.

Grabar A., Sculptures Byzantines du Moyen Âge. II. (XI-XIV Siècle), Paris, A. et J. Picard Publ., 1976, 166 p.

Khroushkova L., Les Monuments Chrétiens de la Côte Orientale de la Mer Noire. Abkhazie IV-XIV Siècles, Turnhout, Brepols Publishers, 2006, 340 p. (Bibliotheque de l'Antiquite Tardive 9).

Khrushkova, L.G., Relief Slab with the Image of Birds from Tsebelda, Sovetskaya arkheologiya [Soviet Archeology], 1977, no. 1, pp. 75-83 (in Russ.).

Khrushkova, L.G., Skul'ptura rannesrednevekovoi Abkhazii $V-X$ veka [Sculpture of the Early Medieval Abkhazia of the 5th-10th Century], Tbilisi, Metsniereba Publ., 1980, $126 \mathrm{p}$.

Miller, A.A., Explorations on the Black Sea Coast of the Caucasus in 1907, Izvestiya Imperatorskoi Arkheologicheskoi komissii [News of the Imperial Archaeological Commission], issue 33, St. Petersburg, V.F. Kirshbauma Publ., 1909, pp. 71-102 (in Russ.).

Strazhev, V.I., Abkhazia of Ruins, Izvestiya Abkhazskogo nauchnogo obshchestva [News of the Abkhazian Scientifi c Society], issue 1. Sukhum, 1925, pp. 131- 169 (in Russ.).

Voronov, Yu.N., Nauchnye trudy: v 7 t. T. III. Taina Tsebel'dinskoi doliny. Drevnyaya Apsiliya [Scientific Works: in 7 volumes. Volume III. The Mystery of the Tsebelda, Valley, Ancient Apsilia]. Sukhum, Abkhazskii Institut Gumanitarnykh Issledovanii ANA Publ., 2010, 468 p.

Voronov, Yu.N., Bgazhba O.Kh., Studies of Medieval Monuments in Tsebelda, Arkheologicheskie otkrytiya 1981-1982 gg. v Abkhazii [Archaeological Discoveries of 1981-1982 in Abkhazia]. Tbilisi, Metsniereba Publ., 1985, pp. 27-35 (in Russ.). 